\title{
Human granulocytic anaplasmosis: First reported case in Canada
}

\author{
Michael D Parkins MD MSc FRCPC ${ }^{1}$, Deirdre L Church ${ }^{1,2,3}$, Xiu Yan Jiang ${ }^{3}$, Daniel B Gregson ${ }^{1,2,3}$
}

MD Parkins, DL Church, XY Jiang, DB Gregson. Human granulocytic anaplasmosis: First reported case in Canada. Can J Infect Dis Med Microbiol 2009;20(3):e100-e102.

Human granulocytic anaplasmosis (HGA) is a tick-borne rickettsial infection of peripheral blood neutrophils caused by Anaplasma phagocytophilum. While this infection is increasingly recognized as endemic throughout much of the United States, no Canadian cases have been previously described, despite the agent being identified in Canadian ticks. Herein we present a case of HGA acquired in an urban Alberta centre. Canadian physicians must be aware of the possibility of tickborne rickettsial diseases as etiology of fever in individuals presenting with leukopenia/lymphopenia, thrombocytopenia and elevated transaminases during periods of tick activity. Prompt recognition and treatment are important in minimizing resultant morbidity and mortality.

Key Words: Anaplasma phagocytophilum; Ehrlichia; Ixodes; Leukopenia; Thrombocytopenia; Ticks

\section{Anaplasmose granulocytaire humaine : premier cas signalé au Canada}

L'anaplasmose granulocytaire humaine $(\mathrm{AGH})$ est une rickettsiose, plus particulièrement une infection des neutrophiles du sang périphérique, transmise par les tiques et causée par Anaplasma phagocytophilum. Bien que la maladie soit de plus en plus reconnue comme endémique dans une grande partie des États-Unis, aucun cas n'avait été signalé jusqu'à maintenant, au Canada, malgré le fait que l'agent causal, lui, ait été détecté dans des tiques au pays. Il sera donc question, dans le présent article, d'un cas d'AGH apparu dans un centre urbain, en Alberta. Les médecins, au Canada, doivent penser à une rickettsiose transmise par les tiques comme cause possible de fièvre chez les personnes présentant une leucopénie ou une lymphocytopénie, une thrombocytopénie et un taux élevé de transaminases durant la période d'activité des tiques. Il est important de reconnaître la maladie et de la traiter rapidement afin de diminuer la morbidité et la mortalité.

\section{CASE PRESENTATION}

An 82-year-old man was admitted to hospital in late June with progressive fever and confusion. The patient was native to Calgary, Alberta and had not travelled outside the city for many years. While previously well, in the five days preceding hospitalization progressive confusion and an increasing frequency of falls were noted. On admission he had a temperature of $39.1^{\circ} \mathrm{C}$, and was hypoxic on room air $(85 \%)$. A chest $\mathrm{x}$-ray showed evidence of pulmonary edema and a focal infiltrate could not be ruled out. He had normal computed tomography and magnetic imaging brain scans. Initial blood work was remarkable for leukopenia; total $3.7 \times 10^{9} / \mathrm{L}$ (normal $4.0 \times 10^{9} / \mathrm{L}$ to $\left.11.0 \times 10^{9} / \mathrm{L}\right)$, (lymphocytes; $0.1 \times 10^{9} / \mathrm{L}$ [normal $0.7 \times 10^{9} / \mathrm{L}$ to $3.5 \times 10^{9} / \mathrm{L}$ ] and neutrophils; $3.3 \times 10^{9} / \mathrm{L}$ [normal; $\left.2.0 \times 10^{9} / \mathrm{L}-8.0 \times 10^{9} / \mathrm{L}\right]$ ), thrombocytopenia; $114 \times 10^{9} / \mathrm{L}$ (normal; $\left.150 \times 10^{9} / \mathrm{L}-400 \times 10^{9} / \mathrm{L}\right)$, mild renal insufficiency with a glomerular filtration rate of $42 \mathrm{~mL} / \mathrm{min} / 1.73 \mathrm{~m}^{2}$ (normal greater than $60 \mathrm{~mL} / \mathrm{min} / 1.73 \mathrm{~m}^{2}$ ) and a creatine kinase of $2509 \mathrm{U} / \mathrm{L}$ (normal $0 \mathrm{U} / \mathrm{L}$ to $195 \mathrm{U} / \mathrm{L}$ ). His initial diagnosis was congestive heart failure with concomitant community-acquired pneumonia and rhabdomyolysis. He was admitted, diuresed and started on intravenous ceftriaxone $1 \mathrm{~g}$ every $24 \mathrm{~h}$.

The following day an engorged tick (later identified as Ixodes scapularis) was recognized and subsequently removed from his right arm. Further investigations revealed an increased aspartate aminotransferase of $102 \mathrm{U} / \mathrm{L}$ (normal $8 \mathrm{U} / \mathrm{L}$ to $40 \mathrm{U} / \mathrm{L}$ ) with otherwise normal liver enzymes and a progressive thrombocytopenia to a nadir of $34 \times 10^{9} / \mathrm{L}$. A peripheral smear revealed evidence of intracytoplasmic inclusions within granulocytes consistent with rickettsial morulae (Figure 1), suggesting the

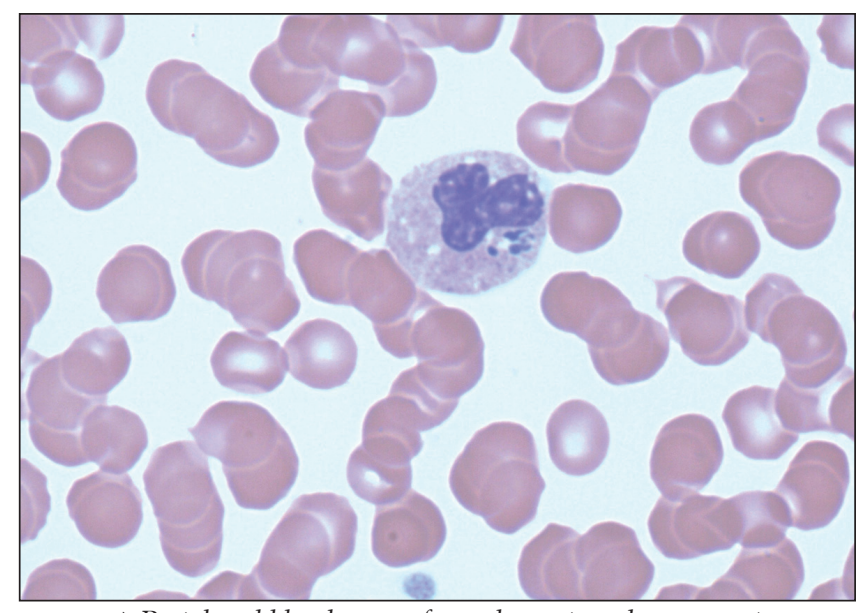

Figure 1) Peripheral blood smear from the patient demonstrating morulae within a peripheral neutrophil containing Anaplasma phagocytophilum (Wright stain, original magnification $\times 1000$ )

diagnosis of human granulocytic anaplasmosis (HGA). The patient was immediately started on doxycycline $100 \mathrm{mg}$ by mouth twice daily and made a complete recovery within 48 h. Polymerase chain reaction of whole blood performed at Mayo Medical Laboratories (Rochester, Minnesota) was positive for Anaplasma phagocytophilum. He was believed to have acquired the tick(s) during one of many repeated forays into local urban wooded recreational areas foraging for golf balls. Interestingly, polymerase chain reaction analysis of the removed tick performed at National Microbiology Laboratory of the Public Health Agency of Canada for HGA was negative.

Departments of ${ }^{1}$ Medicine and ${ }^{2}$ Pathology and Laboratory Medicine, University of Calgary; ${ }^{3}$ Calgary Laboratory Services, Calgary, Alberta Correspondence: Dr Michael Parkins, Division of Infectious Disease, University of Calgary, Doctor's Lounge, Foothills Medical Centre,

1403-29 Street Northwest, Calgary, Alberta T2N 2T9. Telephone 403-220-5951, fax 403-270-2772, e-mail mdparkin@ucalgary.ca 
TABLE 1

Tick-borne diseases endemic in North America that are transmissible to humans

\begin{tabular}{|c|c|c|c|c|c|}
\hline Disease & Causative agent & Vector & Area of endemicity & $\begin{array}{l}\text { Common clinical } \\
\text { features }\end{array}$ & Preferred treatment \\
\hline Tick paralysis (12) & $\begin{array}{l}\text { Adherent tick - tick toxin } \\
\text { mediated }\end{array}$ & $\begin{array}{c}\text { Dermacentor species > } \\
\text { Amblyomma species } \\
\text { >> Ixodes species }\end{array}$ & $\begin{array}{l}\text { W Canada and W-central } \\
\text { USA }\end{array}$ & $\begin{array}{l}\text { Ascending symmetrical } \\
\text { paralysis. Absence of } \\
\text { fever }\end{array}$ & $\begin{array}{l}\text { Tick removal, supportive } \\
\text { care }\end{array}$ \\
\hline $\begin{array}{l}\text { Human granulocytic } \\
\text { anaplasmosis }(5,6)\end{array}$ & Anaplasma phagocytophilum & $\begin{array}{l}\text { Ixodes scapularis/ } \\
\text { Ixodes pacificus }\end{array}$ & $\begin{array}{l}\text { NE, mid-Atlantic, mid-W } \\
\text { and Pacific NW USA, } \\
\text { S Ontario, S Nova Scotia }\end{array}$ & $\begin{array}{l}\text { Fever, headache, } \\
\text { absence of rash }\end{array}$ & Doxycycline \\
\hline Lyme disease (1) & Borrelia burgdorferi & I scapularis/l pacificus & $\begin{array}{l}\text { NE, Mid-Atlantic, mid-W } \\
\text { and Pacific NW USA, } \\
\text { S Ontario, S Nova Scotia, } \\
\text { S British Columbia }\end{array}$ & $\begin{array}{l}\text { Early: erythema migrans } \\
\text { rash; Late: polyarthritis, } \\
\text { neurological } \\
\text { abnormalities }\end{array}$ & $\begin{array}{l}\text { Amoxicillin, doxycycline, } \\
\text { ceftriaxone }\end{array}$ \\
\hline Babesiosis (13) & $\begin{array}{l}\text { Babesia microti, } \\
\text { Babesia species }\end{array}$ & I scapularis & NE and mid-W USA & $\begin{array}{l}\text { Isolated fever, fulminant } \\
\text { disease possible in } \\
\text { asplenics }\end{array}$ & $\begin{array}{l}\text { Atovaquone + azithromycin } \\
\text { OR clindaymycin + qui- } \\
\text { nine }\end{array}$ \\
\hline $\begin{array}{l}\text { Rocky Mountain } \\
\text { spotted fever (6) }\end{array}$ & Rickettsia rickettsii & Dermacentor species & SE and central USA & $\begin{array}{l}\text { Fever, generalized } \\
\text { macular-papular rash. } \\
\text { High mortality }\end{array}$ & Doxycycline \\
\hline $\begin{array}{r}\text { Human monocytic } \\
\text { ehrlichiosis }(5,6)\end{array}$ & Ehrlichia chaffeensis & $\begin{array}{c}\text { Amblyomma species }>> \\
\text { Dermacentor species }\end{array}$ & $\begin{array}{l}\text { South-central, SE and } \\
\text { mid-Atlantic USA }\end{array}$ & $\begin{array}{l}\text { Fever, headache, } \\
\text { absence of rash }\end{array}$ & Doxycycline \\
\hline Tularemia (14) & Francisella tularensis & $\begin{array}{l}\text { Amblyomma species/ } \\
\text { Dermacentor species }\end{array}$ & $\begin{array}{l}\text { Central, S-central, Pacific } \\
\text { NW USA }\end{array}$ & $\begin{array}{l}\text { Fever, ulcer at inocula- } \\
\text { tion site and lymph- } \\
\text { adenitis }\end{array}$ & $\begin{array}{l}\text { Gentamicin or tobramycin } \\
\pm \text { chloramphenicol or } \\
\text { doxycycline }\end{array}$ \\
\hline Q fever (14) & Coxiella burnetii & Dermacentor species & Endemic in North America & $\begin{array}{l}\text { Febrile illness, } \\
\text { pneumonia, hepatitis }\end{array}$ & $\begin{array}{l}\text { Doxycycline } \pm \\
\text { hydroxychloroquine }\end{array}$ \\
\hline Relapsing fever (15) & $\begin{array}{l}\text { Borrelia species including } \\
\text { Borrelia hermsii }\end{array}$ & Ornithodoros species & $\begin{array}{l}\text { W, S-central USA and } \\
\text { W Canada }\end{array}$ & $\begin{array}{l}\text { Remittent bouts of high- } \\
\text { grade fevers }\end{array}$ & $\begin{array}{l}\text { Doxycycline or } \\
\text { chloramphenicol }\end{array}$ \\
\hline $\begin{array}{l}\text { Powassan } \\
\text { encephalitis (16) }\end{array}$ & Powassan virus & Ixodes species & NE USA and E Canada & $\begin{array}{l}\text { Fever, weakness, } \\
\text { and encephalitis } \pm \\
\text { meningitis }\end{array}$ & Supportive care \\
\hline $\begin{array}{l}\text { Colorado tick } \\
\text { fever (17) }\end{array}$ & Colorado tick fever virus & Dermacentor species & W USA and SW Canada & $\begin{array}{l}\text { Fever, myalgia, head- } \\
\text { ache }\end{array}$ & Supportive care \\
\hline
\end{tabular}

This list is not all inclusive. E East; N North; S South; W West; USA United States

\section{DISCUSSION}

There are a number of medically important ticks capable of transmitting zoonoses to humans found in North America (Table 1). In particular, Ixodes species ticks are present in many parts of Canada. Self sustaining endemic populations of I scapularis are known to exist in eastern Canada (northeast shores of Lakes Ontario and Erie, and southeast Nova Scotia, and possibly southern Quebec, Manitoba and New Brunswick), whereas Ixodes pacificus, a vector less commonly implicated in tick-borne disease, is found in many areas of British Columbia (1). However, a recent passive surveillance study of I scapularis ticks collected from humans and animals in Canada found that more than $98 \%$ of ticks were identified in areas outside of those distinct geographic locations with replicating populations of ticks (representing provinces from Saskatchewan to Newfoundland) (2). Indeed, the majority of ticks in Canada are suspected of being adventitiously introduced by northerly migrating birds. In fact, Ogden et al (3) have extrapolated data collected from more than 39,000 northward migratory birds in the spring of 2005 and 2006 to estimate that between 50 and 175 million I scapularis ticks are imported into Canada each year.

HGA is a tick-borne rickettsial infection of neutrophils caused by A phagocytophilum. While HGA has previously been described in many parts of the United States (northeastern, mid-Atlantic, upper-midwest and Pacific northwest states),
Europe and Asia, it has not been described in Canada (although the agent has been found in Canadian ticks) (4). A reportable condition in the United States, documented infections tripled from 2000 to 2005. In 2005, there were 700 cases reported to the Center for Disease Control and Prevention (5). The true burden of infection may be much higher because seroprevalence studies in populations living in areas of high endemicity show $0.6 \%$ to $14.9 \%$ of individuals have reactive antibodies. However, prospective studies do not show this same burden of disease; therefore, it is unknown if this relates to mild or subacute infection or rather to cross-reacting antibodies to other agents.

Human infection occurs as a result of a bite from a tick infected with A phagocytophilum. Patients often present with febrile illness associated with headache, fever and myalgias (4-6). Rash is not a common manifestation of disease. Most patients report tick exposure one to two weeks before the onset of infection. Laboratory findings often include thrombocytopenia, leukopenia/lymphopenia and elevated hepatic transaminases. Approximately $50 \%$ of patients with documented HGA require hospital admission and 7\% require intensive care support. Unlike Rocky Mountain spotted fever and human monocytic ehrlichiosis, death is uncommon and occurs in only $0.5 \%$ of documented infections. Complications are uncommon but include sepsis-like syndromes, acute respiratory distress syndrome, heart failure, acute renal failure, rhabdomyolysis and 
opportunistic infections. Risk factors for adverse outcomes include advanced age and host immune-suppression. Recently, secondary cases of human to human nosocomial transmission of HGA were documented in China, associated with large volume exposure to the index patient's blood and respiratory secretion (7).

Anaplasma species are uniformly susceptible to tetracyclines $(4,5)$. Because of favourable pharmacokinetics, treatment with doxycycline $100 \mathrm{mg}$ by mouth twice daily for five to 14 days is recommended in patients for whom the drug is not contraindicated. For those with history of allergy, pregnancy or young age, rifampin serves as alternate therapy. Patients typically exhibit full recovery within $24 \mathrm{~h}$ to $48 \mathrm{~h}$ of therapy.

The majority of I scapularis ticks are not infected with infectious disease agents that are transmissible to humans. Rates of infection vary greatly depending on region where ticks were collected but Canadian data suggests A phagocytophilum affects $0.4 \%$ of I scapularis (United States rates are much higher, at $4.7 \%)(3,8)$. Other common infections transmitted by I scapularis ticks include Lyme disease (caused by Borrelia burgdorferi), rickettsial species and babesiosis (caused by Babesia microti), although the later two have not been described as endemic to Canada. There has, however, been one case of transfusionassociated babesiosis acquired in Canada where the blood donor had travelled to endemic zones in the United States (9). Multiply infected ticks are occasionally found, predominately in the eastern and mid-eastern parts of the United States, leading to coinfections with more than one individual tick-borne pathogen (5). There is increasing concern that through environmental changes, including global warming, there will be an associated expansion of tick populations to many other areas of Canada and with them, potentially tick-borne illnesses (10). High-density populations of suitable rodent/white tail deer populations exist in many parts of Canada, which could readily support their expansion.

While HGA has not previously been described in Canada, there have been occasions in which anaplasmosis has been described in animals. Most recently, three separate cases of canine anaplasmosis were described in Saskatchewan dogs presenting with fever, lethargy, vomiting and diarrhea (11). Furthermore, A phagocytophilum-infected I scapularis ticks have been infrequently identified from migratory birds in eastern Canada (3). Neither HGA nor any other tick-borne disease is currently a mandatory reportable illness in Canada.

In the case described herein, it is apparent that A phagocytophilum from a tick acquired in Canada has resulted in the first case of locally transmitted HGA. Locally reproducing populations of I scapularis are not known to exist in the province of Alberta and as such this likely represents an adventitiously introduced tick. The fact that the adherent tick was negative for A phagocytophilum when screened at the National Microbiology Laboratory should not be surprising, given that normal time from tick acquisition to disease is seven to 14 days $(4,5)$, much longer then tick adherence. As such, it is likely that this gentleman unknowingly had repeated recent tick exposures and a previous tick was responsible for disease transmission.
The present case illustrates that Canadians are at risk for tick-borne illnesses not previously thought to occur in Canada. There is an urgent need for Canadian-specific data regarding the epidemiology of ticks and tick-borne agents in Canada. Patients presenting during times of tick activity (May to September) with fever, leukopenia/lymphopenia, thrombocytopenia and increased serum transaminases should have rickettsial diseases such as HGA included in the differential diagnosis. Lack of historical or epidemiological features for tick exposure should not exclude the diagnosis when the clinical features are present, as illustrated by the present case.

DISCLOSURE: All authors are free of potential conflicts. The patient described herein has provided written consent for the publication of this case report.

\section{REFERENCES}

1. Ogden NH, Artsob H, Lindsay LR, Sockett PN. Lyme disease: A zoonotic disease of increasing importance to Canadians. Can Fam Physician 2008;54:1381-4.

2. Ogden NH, Trudel L, Artsob H, et al. Ixodes scapularis ticks collected by passive surveillance in Canada: Analysis of geographic distribution and infection with Lyme borreliosis agent Borrelia burgdorferi. J Med Entomol 2006;43:600-9.

3. Ogden NH, Lindsay LR, Hanincova K, et al. Role of migratory birds in introduction and range expansion of Ixodes scapularis ticks and of Borrelia burgdorferi and Anaplasma phagocytophilum in Canada. Appl Environ Microbiol 2008;74:1780-90.

4. Bakken JS, Dumler JS. Clinical diagnosis and treatment of human granulocytotropic anaplasmosis. Ann N Y Acad Sci 2006;1078:236-47.

5. Dumler JS, Madigan JE, Pusterla N, Bakken JS. Ehrlichioses in humans: Epidemiology, clinical presentation, diagnosis, and treatment. Clin Infect Dis 2007;45(Suppl 1):S45-51.

6. Chapman AS, Bakken JS, Folk SM, et al. Diagnosis and management of tickborne rickettsial diseases: Rocky Mountain spotted fever, ehrlichioses, and anaplasmosis - United States: A practical guide for physicians and other health-care and public health professionals. MMWR Recomm Rep 2006;55:1-27.

7. Zhang L, Liu Y, Ni D, et al. Nosocomial transmission of human granulocytic anaplasmosis in China. JAMA 2008;300:2263-70.

8. Dumler JS, Choi KS, Garcia-Garcia JC, et al. Human granulocytic anaplasmosis and Anaplasma phagocytophilum. Emerg Infect Dis 2005;11:1828-34.

9. Kain KC, Jassoum SB, Fong IW, Hannach B. Transfusiontransmitted babesiosis in Ontario: First reported case in Canada. CMAJ 2001;164:1721-3.

10. Ogden NH, Maarouf A, Barker IK, et al. Climate change and the potential for range expansion of the Lyme disease vector Ixodes scapularis in Canada. Int J Parasitol 2006;36:63-70.

11. Dickinson R. Anaplasma phagocytophilum infection in three dogs: Potential for an emerging infectious disease concern in Saskatchewan? Animal Health Perspectives 2008;4:2-3.

12. Adler K. Tick paralysis. Can Med Assoc J 1966;94:550-1.

13. Vannier E, Gewurz BE, Krause PJ. Human babesiosis. Infect Dis Clin North Am 2008;22:469-88, viii-ix.

14. Choi E. Tularemia and $Q$ fever. Med Clin North Am 2002;86:393-416.

15. Dworkin MS, Schwan TG, Anderson DE, Jr. Tick-borne relapsing fever in North America. Med Clin North Am 2002;86:417-33, viii-ix.

16. Gholam BI, Puksa S, Provias JP. Powassan encephalitis: A case report with neuropathology and literature review. CMAJ 1999; 161:1419-22.

17. Klasco R. Colorado tick fever. Med Clin North Am 2002;86:435-40, ix. 


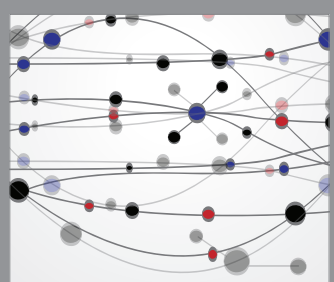

The Scientific World Journal
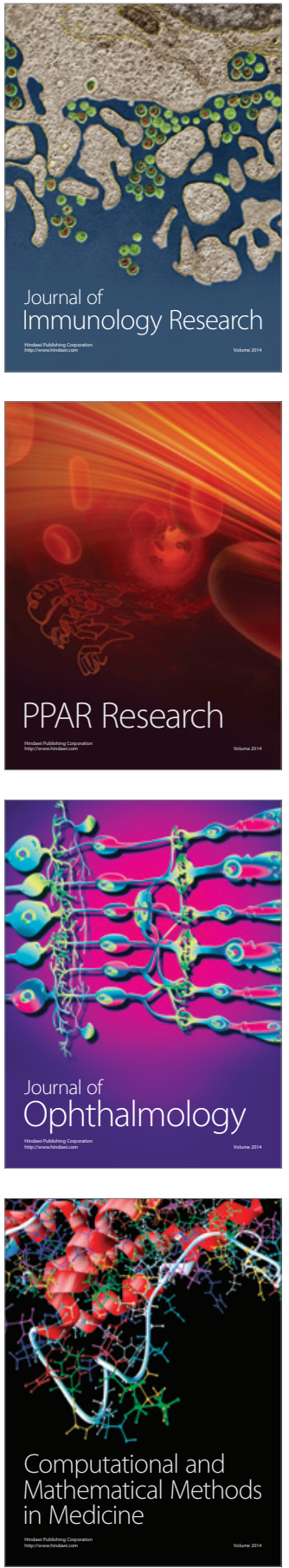

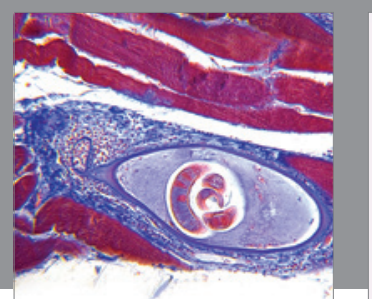

Gastroenterology Research and Practice

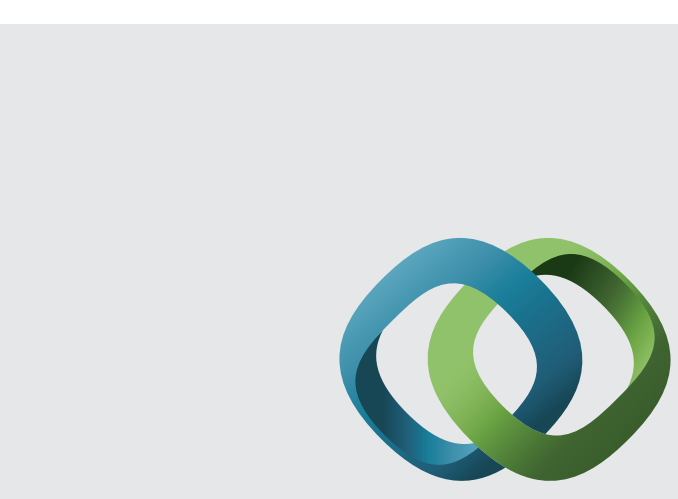

\section{Hindawi}

Submit your manuscripts at

http://www.hindawi.com
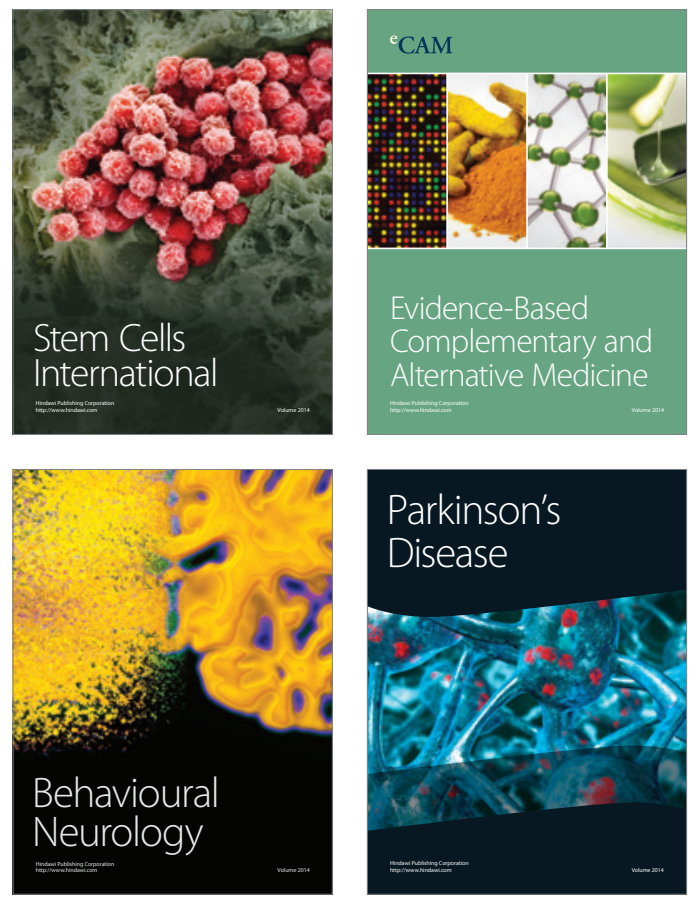
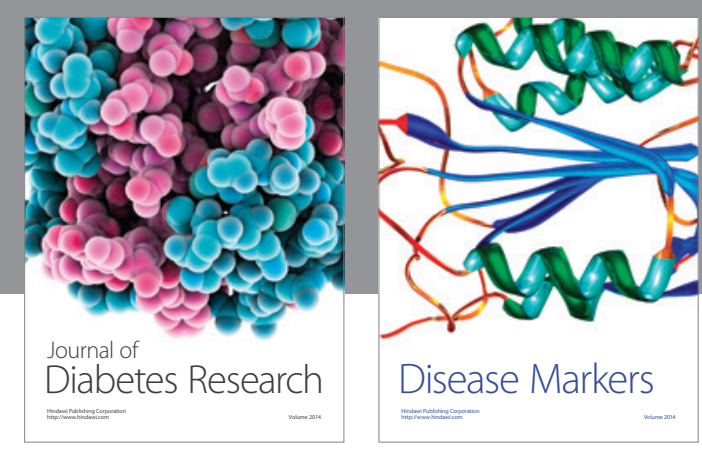

Disease Markers
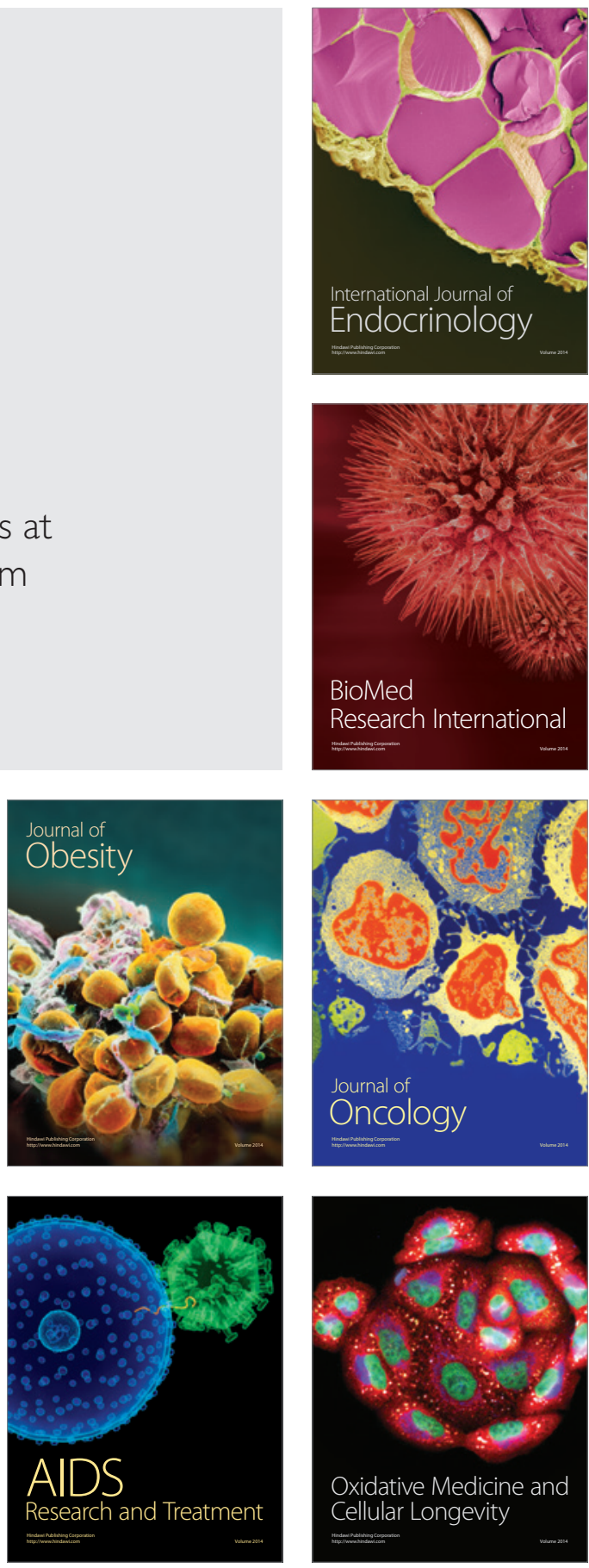